\title{
THORNTHWAITE AND MATHER SOIL WATER BALANCE MODEL ADAPTED FOR ESTIMATION OF REAL EVAPOTRANSPIRATION OF THE PASTURE
}

Fabiana da Costa Barros ${ }^{1}$ (D), Suelen da Costa Faria Martins' (D), Gustavo Bastos Lyra ${ }^{3}$ (D), Leonardo Duarte Batista da Silva ${ }^{2}$ (D), João Paulo Francisco ${ }^{4}$, Marcel Carvalho de $\mathrm{Abreu}^{3}$ (D) \& Guilherme Bastos Lyra ${ }^{5}$

1 - Federal Fluminense University, Department of Agricultural and Environmental Engineering, Niterói, Rio de Janeiro, Brazil

2 - Federal Rural University of Rio de Janeiro, Department of Agricultural and Environmental Engineering, Seropédica, Rio de Janeiro, Brazil

3 - Federal Rural University of Rio de Janeiro, Department of Environmental Sciences, Seropédica, Rio de Janeiro, Brazil

4 - State University of Maringá, Department of Agronomy, Umuarama, Paraná, Brazil

5 - Federal University of Alagoas, Center of Agrarian Sciences, Rio Largo, Alagoas, Brazil

\section{Keywords:}

Agrometeorological Modeling

Bowen ratio

Water Consumption

Single Crop Coefficient

\begin{abstract}
Determining the real water requirement for pastures is essential for the rational use of irrigation. The aim of this work was to assess the crop coefficient and performance of the Thornthwaite and Mather soil water balance ( $\mathrm{ThM}$ ) adapted to estimate the daily actual evapotranspiration $\left(\mathrm{ET}_{\mathrm{a}}\right)$ of a pasture in relation to the Bowen ratio - energy balance method (BREB). The experiment was carried out from July 2018 to June 2019 in Cachoeiras de Macacu, Rio de Janeiro State (RJ) (22 ${ }^{\circ} 27^{\prime} \mathrm{S} ; 42^{\circ}$ $45^{\prime} \mathrm{W}$ and $30 \mathrm{~m}$ altitude). Micrometeorological and meteorological measurements were conducted in a micrometeorological tower installed in the pasture and also in an automatic weather station, located $1 \mathrm{~km}$ from the pasture area. The ThM model was evaluated using linear regression between $\mathrm{ET}_{\mathrm{a}}$ determinate from BREB and the estimates from ThM using its coefficient of determination $\left(\mathrm{R}^{2}\right)$ and the modified Willmott agreement index $\left(\mathrm{d}_{\mathrm{m}}\right)$. The ThM model underestimated (between 11 and $16 \%$ ) the $\mathrm{ET}_{\mathrm{a}}$ for all seasons, except for spring, which overestimated by $1 \%$. The highest precision and accuracy of the estimates were observed in autumn $\left(\mathrm{R}^{2}=0.84\right.$ and $\left.\mathrm{d}_{\mathrm{m}}=0.68\right)$ and spring $\left(\mathrm{R}^{2}=0.83\right.$ and $\left.\mathrm{d}_{\mathrm{m}}=0.82\right)$. In summer $\left(\mathrm{R}^{2}=0.56\right.$ and $\left.\mathrm{d}_{\mathrm{m}}=0.73\right)$ and winter $\left(\mathrm{R}^{2}=0.43\right.$ and $\mathrm{d}_{\mathrm{m}}=0.66$ ), the lower performance was caused by the inability of the model to represent water extraction from the soil in dry periods.
\end{abstract}

\section{Palavras-chave:}

Razão de Bowen

Modelagem Agrometeorológica

Coeficiente de Cultivo Único

Consumo Hídrico de Pastagens

\section{MODELO DE BALANÇO DE ÁGUA NO SOLO DE THORNTHWAITE E MATHER (ThM) ADAPTADO PARA ESTIMATIVA DA EVAPOTRANSPIRAÇÃO REAL (ETR) DE PASTAGEM}

\section{RESUMO}

Conhecer a real demanda de água das pastagens é essencial para o uso racional da irrigação. O objetivo do presente trabalho foi avaliar o coeficiente de cultivo e o desempenho do modelo de balanço de água de Thornthwaite e Mather (ThM) adaptado para estimativa da evapotranspiração real (ETR) diária de uma pastagem em relação ao método do balanço de energia - razão de Bowen (BERB). O experimento foi conduzido no período de julho de 2018 a junho de 2019 no município de Cachoeiras de Macacu, RJ ( $22^{\circ} 27^{\prime}$ S; 42 $42^{\circ}$ 'W e 30 m de altitude). Medidas micrometeorológicas e meteorológicas foram realizadas em uma torre instalada na pastagem e por uma estação meteorológica automática, localizada a $1 \mathrm{~km}$ da área de pastagem. O modelo ThM foi avaliado por meio da regressão linear entre ETR determinada pelo BERB e as estimativas pelo ThM, por seu coeficiente de determinação $\left(\mathrm{R}^{2}\right)$ e o índice de concordância de Willmott modificado $\left(\mathrm{d}_{\mathrm{m}}\right)$. O modelo de ThM subestimou (de 11 a $16 \%$ ) as estimativas de ETR para os períodos analisados, com exceção da primavera, que superestimou em $1 \%$. As maiores precisões e exatidões das estimativas foram observadas no outono $\left(\mathrm{R}^{2}=0,84\right.$ e d $\mathrm{m}=$ $0,68)$ e primavera $\left(\mathrm{R}^{2}=0,83\right.$ e $\left.\mathrm{d}_{\mathrm{m}}=0,82\right)$. No verão $\left(\mathrm{R}^{2}=0,56\right.$ e d $\left.\mathrm{d}_{\mathrm{m}}=0,73\right)$ e inverno $\left(\mathrm{R}^{2}=0,43\right.$ e d $=0,66)$, o menor desempenho foi devido a inabilidade do modelo em representar a extração de água do solo em períodos de ausência de chuvas. 


\section{INTRODUCTION}

According to the prediction made by the Food and Agriculture Organization of the United Nations (FAO), it is estimated that by 2050 , the world population will be approximately 9.7 billion (FAO, 2018). Thus, it is essential to increase agricultural productivity, associated with the rational and optimized use of natural resources, in order to supply the demand for food sustainably.

In this context, pastures are decisive in the Brazilian agricultural sector, as they are characterized as the basis for feeding the Brazilian herds (RETORE et al., 2019). Thus, the correct management of forage becomes essential, as it directly provides an increase in the productivity of livestock activity (AGUIAR et al., 2017).

Irrigation is a practice that can be used to optimize crop management, as it allows the reduction of losses caused by water deficit and, as a consequence, increased productivity (ANTONIEL et al., 2016; SANCHES et al., 2017b). However, it is among agricultural activities with the highest water consumption, requiring the control of water supply and demand, optimizing decision-making (BOSI et al., 2020). Therefore, for the practice to reach its potential, it is necessary to know the real water demand of the crops.

Evapotranspiration (ET) represents the transfer of water from the surface to the atmosphere through the simultaneous occurrence of evaporation and transpiration processes (CRUZ et al., 2017). As a result, ET is an essential factor in estimating the crop water demand. Several approaches have been proposed to obtain it, among them, direct methods (lysimeters), empirical models (e.g., Thornthwaite, Camargo, Hargreaves-Samani, Jensen-Haise, Makkink) or physical-physiological (PenmanMonteith), micrometeorological (e.g., Bowen ratio - energy balance, eddy correlation, aerodynamic method) and through the soil water balance (GOMES et la., 2015a; SILVA et al., 2016).

The Bowen ratio - energy balance (BREB) is a micrometeorological method that has been widely used as a standard in determining the flux of latent heat ( $\mathrm{LH})$ and sensitive heat $(\mathrm{H})$ of several crops and allows to obtain the evapotranspiration (ET) (SILVA et al., 2018; WALLS et al., 2020).
However, BREB requires measurements of micrometeorological elements, resulting in its limitation, especially for small and medium farmers. Alternatively, the soil water balance (SWB) allows estimating ET by quantifying the inflows and outflows of water in the soil, as it is based on the mass conservation principle (O'REILLY et al., 2020). As it only requires soil and weather (rain and evapotranspiration) physical-hydric parameters, SWB is characterized by being a more accessible approach.

Thus, the aim of this study was to evaluate the crop coefficient and the performance of the Thornthwaite and Mather BH model adapted to estimate ETR of a pasture area, in relation to the estimates obtained by the BREB method, from July 2018 to June 2019.

\section{MATERIAL AND METHODS}

\section{Study area and micrometeorological/meteorological} measurements

The experiment was carried out on a pasture area located in the municipality of Cachoeiras de Macacu, Rio de Janeiro State (RJ) $\left(22^{\circ} 27^{\prime} \mathrm{S} ; 42^{\circ}\right.$ $45^{\prime} \mathrm{W}$ and $30 \mathrm{~m}$ altitude). The area covered 30 hectares cultivated with Brachiaria and fortnightly occupied, on average by 160 Nellore animals. The climate in the region, according to Köppen's classification, is Aw -a Humid Tropical Megathermal, with a dry season in winter (ALVARES et al., 2013).

For soil classification, six trenches were opened around the micrometeorological mast (MM). The profiles were described morphologically according to the methodology of Santos et al. (2018) and the soil was classified as typical Tb Melanic Gleisol with a texture between loam sandy and sand (Table 1). Such types of soil are characterized by occurring in flat terrains of floodplains and presenting a high level of the water table.

For physical-water analyses, three points were randomly selected around the MM. Three undisturbed samples were collected at each point at the depths of $0.10,0.30$, and $0.60 \mathrm{~m}$, and later, the samples were taken to the Soil and Water Quality Laboratory at the Escola Superior de Agricultura "Luiz de Queiroz", ESALQ. Moisture at the field 
capacity $\left(0.42 \mathrm{~m}^{3} \mathrm{~m}^{-3}\right)$ and permanent wilting point $\left(0.19 \mathrm{~m}^{3} \mathrm{~m}^{-3}\right)$ was obtained through the soil water retention curve. Analyses of hydraulic conductivity and infiltration rate were also carried out.

Micrometeorological measurements were performed in a $4 \mathrm{~m}$ high $\mathrm{MM}$ installed on the pasture area. The micrometeorological station was composed of several instruments, described in Table 2. Rainfall data from an automatic meteorological station, installed $1 \mathrm{~km}$ from the experimental area were also used. For this experiment, it was evaluated the period from June 2018 to July 2019, which covered winter, spring, summer, and autumn.

\section{Bowen ratio -Energy balance (BREB)}

The energy balance consists of the energy conservation law. It is made up of the radiation balance, heat flux in the soil, sensitive heat flux and latent heat flux, which corresponds to ET (Equation 1). To obtain the energy balance, data from the MM were used, which were stored every 10 seconds and, subsequently, an average was performed every 30 minutes. The collected data were analyzed according to the methodology (PEREZ et al., 1999) proposed for disposal and selection (Equation 1).

$$
\mathrm{R}_{\mathrm{n}}-\mathrm{H}-\mathrm{LE}-\mathrm{G}=0
$$

Where,

$\mathrm{R}_{\mathrm{n}}=$ net radiation, $\mathrm{W} \cdot \mathrm{m}^{-2}$;

$\mathrm{H}=$ sensitive heat flux, W. $\mathrm{m}^{-2}$;

$\mathrm{LE}=$ latent heat flux, $\mathrm{W} \cdot \mathrm{m}^{-2}$; and

$\mathrm{G}=$ heat flux in the soil, W.m ${ }^{-2}$

Bowen (1926) incorporated the ratio between the fluxes of sensitive and latent heat. This relationship was denominated Bowen's ratio $(\beta)$, which can also be determined by the relationship between the vertical gradients of temperature $(\Delta T$, $\left.{ }^{\circ} \mathrm{C}\right)$ and air humidity $(\Delta \mathrm{e}, \mathrm{kPa})$ (Equation 2$)$.

$\beta=\frac{\mathrm{H}}{\mathrm{LE}}=\gamma \frac{\Delta \mathrm{T}}{\Delta \mathrm{e}}$

Where,

$\gamma=$ Psychometric coefficient, $\mathrm{kPa} .{ }^{\circ} \mathrm{C}^{-1}$.

The psychrometric coefficient was obtained using

Table 1. Particle size analysis and textural classification per horizon, performed on the six profiles located in the pasture area in Cachoeiras de Macacu, RJ

\begin{tabular}{ccccc}
\hline \multirow{2}{*}{ Horizon } & Clay & Silt & Sand & Textural Class \\
\cline { 2 - 4 } & & ${\text { dag. } \mathrm{kg}^{-1}}^{-1}$ & & \\
$\mathrm{~A}$ & 26 & 37 & 37 & Loam \\
$\mathrm{Bg}$ & 17 & 31 & 52 & Sandy Loam \\
$\mathrm{B} / \mathrm{C}$ & 27 & 28 & 45 & Loam \\
$\mathrm{Cg}$ & 8 & 19 & 73 & Loamy Sand \\
\hline
\end{tabular}

Table 2. Description of the sensors installed in the experimental area

\begin{tabular}{cccccc}
\hline Parameter & Sensor & Model & Brand & Country & Depth (m) \\
\cline { 1 - 5 } Liquid radiation & Radiation balace & LP-NET-14 & Delta Ohm & Itália & 1.5 \\
\hline $\begin{array}{c}\text { Air humidity and } \\
\text { temperature }\end{array}$ & Thermohygrometer & DB-TH1-SDI & dualBASE & EUA & 1.15 e 1.58 \\
\hline Wind speed & Anemometer & GILL-1405 & Gill instruments & Reino Unido & $\begin{array}{c}1.23 ; 1.68 ; \\
2.34 \text { e 3.00 }\end{array}$ \\
\hline Soil heat flux & Flow plate & HFP01 & $\begin{array}{c}\text { Hukseflux Thermal } \\
\text { Sensors }\end{array}$ & EUA & 0.05 \\
\hline $\begin{array}{c}\text { Data acquisition and } \\
\text { storage }\end{array}$ & Data logger & CR3000 & $\begin{array}{c}\text { Campbell Scientific } \\
\text { Inc }\end{array}$ & EUA & - \\
\hline
\end{tabular}




\section{Equatiog $9067 \mathrm{P}_{\mathrm{atm}}$}

where,

$\mathrm{P}_{\mathrm{atm}}=$ Atmospheric pressure, $\mathrm{kPa}$.

By replacing equation 2 into the 1 and reorganizing it, the $\mathrm{ET}_{\mathrm{a}}$ - $\mathrm{BREB}\left(\mathrm{ETa}_{\beta}\right)$ was obtained:

$$
\operatorname{ETa}_{\beta}=\frac{1800}{\lambda} \frac{(\mathrm{Rn}-\mathrm{G})}{(1+\beta)}
$$

Where,

$\lambda=$ latent heat of vaporization, $2,45 \mathrm{MJ} . \mathrm{kg}^{-1}$;

$1800=$ mean time in seconds, from which data were obtained.

\section{Selection of the observations}

To ensure consistent estimates, the criterion established by Perez et al., (1999) was used. Thus, data collected at night and in the early morning were discarded. In addition, to avoid the effects of horizontal gradient fluxes, the sensors were installed within the constant or equilibrium limit layer (MONTEITH; UNSWORTK,1990), with a border of approximately $300 \mathrm{~m}$, determined according to (LYRA; PEREIRA, 2007).

\section{Soil water balance - Thornthwaite and Mather}

The soil water balance is based on the law of mass conservation, represented by the variation of soil water storage (Equation 5). The real evapotranspiration (ETa-ThM) was obtained through the modified WB (LYRA et al., 2020).

$$
\mathrm{ALT}_{\mathrm{i}}=\left(S W_{i}-S W_{i-1}\right)=\mathrm{P}_{\mathrm{i}}-\mathrm{ETa}_{\mathrm{i}}-\mathrm{EXC}_{\mathrm{i}}
$$

Where,

$\mathrm{ALT}=$ change in water storage in the soil, $\mathrm{mm}$; $\mathrm{SW}=$ soil water storage, $\mathrm{mm}$;

$\mathrm{P}=$ precipitation, $\mathrm{mm}$;

$\mathrm{ETa}=$ actual evapotranspiration, $\mathrm{mm}$; and

$\mathrm{EXC}=$ water surplus, $\mathrm{mm}$.

Storage was calculated using Equation 6, and according to the methodology, it is penalized according to water availability, denominated accumulated negative (ACN) (Equation 7).

$$
S W= \begin{cases}C A D \exp \left[\frac{N A C}{C A D}\right] & \text { for }\left(P_{i}-E c_{i}\right)<0 \\ S W_{i-1}+\left(P_{i}-E T c_{i}\right) & \text { for }\left(P_{i}-E c_{i}\right) \geq 0\end{cases}
$$

$\mathrm{NAC}= \begin{cases}\mathrm{NAC}_{\mathrm{i}-1}-\left(\mathrm{P}_{\mathrm{i}}-\mathrm{ET}_{\mathrm{C}_{\mathrm{i}}}\right) & \text { for }\left(P_{i}-\mathrm{ET}_{\mathrm{c}}\right)<0 \\ \mathrm{CAD} \ln \left[\frac{\mathrm{SW}}{\mathrm{CAD}}\right] & \text { for }\left(P_{i}-\mathrm{ET}_{\mathrm{c}}\right) \geq 0\end{cases}$

Where,

$\mathrm{ET}_{\mathrm{c}}=$ crop evapotranspiration.

The Available Water Capacity (AWC) was calculated using Equation 8:

$$
\mathrm{AWC}=1000\left(\theta_{f c}-\theta_{\mathrm{pwp}}\right) \mathrm{Z}_{\mathrm{r}}
$$

Where,

$\mathrm{AWC}=$ Available water capacity, $\mathrm{mm}$;

$\theta_{\text {cc }}=$ soil moisture at field capacity, $(0.42) \mathrm{m}^{3} \cdot \mathrm{m}^{-3}$;

$\theta_{\mathrm{pmp}}^{\mathrm{cc}}=$ soil moisture at permanent wilting point, $(0,23) \mathrm{m}^{3} \cdot \mathrm{m}^{-3}$; e

$\mathrm{Z}_{\mathrm{r}}=$ effective root depth, $\mathrm{m}$.

Once the $\mathrm{K}_{\mathrm{c}}$ was obtained, $\mathrm{ET}_{\mathrm{c}}$ was estimated using the single crop coefficient method suggested in FAO 56 (Equation 9).

$\mathrm{ET}_{\mathrm{c}}=\mathrm{ET}_{o} \cdot \mathrm{Kc}$

Reference evapotranspiration $\left(\mathrm{ET}_{\mathrm{o}}\right)$ was calculated using the Penman-Monteith FAO 56 method (Equation 10).

$\mathrm{ET}_{\mathrm{o}}=\frac{0.408 \Delta\left(\mathrm{R}_{\mathrm{n}}-\mathrm{G}\right)+\gamma \frac{900}{\mathrm{~T}+273} \mathrm{u}_{2}\left(\mathrm{e}_{\mathrm{s}}-\mathrm{e}_{\mathrm{a}}\right)}{\Delta+\gamma\left(1+0.34 \mathrm{u}_{2}\right)}$

Where,

$\mathrm{ET}_{\mathrm{o}}=$ reference evapotranspiration, $\mathrm{mm} \cdot \mathrm{d}^{-1}$;

$\mathrm{R}_{\mathrm{n}}=$ net radiation at surface, $M J \cdot \mathrm{m}^{-2} \mathrm{~d}^{-1}$;

$\mathrm{G}=$ soil heat flux density, $M J \cdot \mathrm{m}^{-2} \mathrm{~d}^{-1}$;

$\mathrm{T}=$ mean daily air temperature, ${ }^{\circ} \mathrm{C}$;

$\mathrm{u}_{2}=$ wind speed at 2 meter height, $\mathrm{m} \cdot \mathrm{s}^{-1}$;

$\mathrm{e}_{\mathrm{s}}=$ saturation vapor pressure, $\mathrm{kPa}$;

$\mathrm{e}_{\mathrm{a}}=$ actual vapor pressure, $\mathrm{kPa}$;

$\Delta=$ slope of the vapor pressure curve, $\mathrm{kPa} .{ }^{\circ} \mathrm{C}^{-1}$;

$\gamma=$ psychrometric coefficient, $\mathrm{kPa} .{ }^{\circ} \mathrm{C}^{-1}$; and

$0.408=$ conversion factor for the term $\left(R_{n}-G\right)$, of MJ.m ${ }^{-2} \mathrm{~d}$ for mm.day ${ }^{-1}$.

Finally, ETa was obtained employing the relationship shown in Equation 11.

$$
\begin{array}{ll}
\mathrm{ETa}=\mathrm{ET}_{\mathrm{c}} & \text { for }\left(\mathrm{P}-\mathrm{ET}_{\mathrm{c}}\right) \geq 0 \\
\mathrm{ETa}=\mathrm{P}+|\mathrm{ALT}| & \text { for }\left(\mathrm{P}-\mathrm{ET}_{\mathrm{c}}\right)<0
\end{array}
$$

Single crop coefficient $\left(K_{c}\right)$

For the calculation of ETc, the crop coefficient 
was used, which was obtained based on experimental data. Therefore, it was selected days considered without water deficit, characterized on the basis of the fraction of water available in the soil (FDA) (Equation 12).

$$
f D A=\frac{\left(\theta-\theta_{\mathrm{pwp}}\right)}{\left(\theta_{f c}-\theta_{\mathrm{pwp}}\right)}
$$

Where,

$\theta=$ soil moisture, $\mathrm{m}^{3} \cdot \mathrm{m}^{-3}$;

$\theta_{\text {pmp }}=$ permanent wilting point, $\mathrm{m}^{3} \cdot \mathrm{m}^{-3}$; and

$\theta_{\mathrm{cc}}^{\mathrm{pmp}}=$ field capacity, $\mathrm{m}^{3} \cdot \mathrm{m}^{-3}$.

The days without water deficit were those that met the criterion $0.8 \leq \mathrm{fDA} \leq 1.1$. In these conditions, $\mathrm{ET}_{\mathrm{c}}=\mathrm{ET}_{\mathrm{a}}$ was characterized (PEREIRA; SEDIYAMA; NOVA, 2013). Next, a linear regression model was used between $\mathrm{ET}_{\mathrm{o}}$ (independent variable) and $\mathrm{ET}_{\mathrm{c}}$ (dependent variable) forced to pass through the origin, so that $\mathrm{K}_{\mathrm{c}}$ was determined by the angular coefficient of the line (Equation 13).

$\mathrm{Y}=\beta_{1} \mathrm{X}$

Where,

$\mathrm{Y}=\mathrm{ET}_{\mathrm{c}}, \mathrm{mm} \cdot \mathrm{d}^{-1}$;

$\mathrm{X}_{\mathrm{i}}=\mathrm{ET}$, mm.d $\mathrm{d}^{-1}$; and

$\beta_{1}=$ angular coefficient.

Data normality was assessed through the Kolmogorov-Smirnov test $(\mathrm{p}<0.05)$, and subsequently the significance of the regression was analyzed using the analysis of variance (ANOVA). The quality of the model adjustment was observed using the coefficient of determination $\left(\mathrm{R}^{2}\right)$ and the standard error of estimate (SES).

\section{Statistical analysis}

The accuracy of the ETa-ThM and $\mathrm{ETa}_{\beta}$ estimates were assessed based on the modified Willmott concordance index $\left(\mathrm{d}_{\mathrm{m}}\right)$ (WILLMOTT; ROBESON;MATSURA, 2012), (Equation 14). The simple linear regression analysis forced to pass at the origin between $\mathrm{ETa}_{\beta}$ (standard) and ETaThM was also applied as well as the coefficient of determination $\left(\mathrm{R}^{2}\right)$ (Equation 15) and the root mean squared error (RMSE) (Equation 16).
$d_{m}=1-\frac{\sum_{i=1}^{N}\left(\left|P_{i}-O i\right|\right)}{\sum_{i=1}^{N}\left[\left(\left|P_{i}-\bar{O}\right|\right)+\left(\left|O_{i}-\bar{O}\right|\right)\right]}$

Where,

$\mathrm{d}_{\mathrm{m}}=$ index of agreement or adjustment;

$\mathrm{P}_{\mathrm{i}}=$ values of predictable ETa_ThM, mm.d d $^{-1}$;

$\mathrm{O}_{\mathrm{i}}=$ values of observed $\mathrm{ETa}_{\beta}, \mathrm{mm} \mathrm{d}^{-1}$;

$\overline{\mathrm{O}}=$ means of the $\mathrm{ETa}_{\beta}, \mathrm{mm} \cdot \mathrm{d}^{-1}$ values; and

$\mathrm{N}=$ number of observations.

$R^{2}=\left(\frac{\sum_{i=1}^{N}\left(O_{i}-\bar{O}\right)\left(P_{i}-\bar{P}\right)}{\sqrt{\left[\sum_{i=1}^{N}\left(O_{i}-\bar{O}\right)^{2}\right]}\left[\sum_{i=1}^{N}\left(P_{i}-\bar{P}\right)^{2}\right]}\right)^{2}$

Where,

$\overline{\mathrm{O}}=$ mean of the values of $\mathrm{ETR}_{\beta}, \mathrm{mm} \cdot \mathrm{d}^{-1}$; and

$\overline{\mathrm{P}}=$ mean of the estimated values of ETR_ThM, mm.d $\mathrm{d}^{-1}$.

$R M S E=\sqrt{\sum_{i=1}^{N}\left[\frac{\left(O_{i}-P_{i}\right)^{2}}{N}\right]}$

Error indices were also used to assess whether the error was related to the model, through systematic error (MSEs) (Equation 17), or whether it was conditioned to external factors, through random error (MSEu), (Equation 18).

$$
\begin{gathered}
\text { MSES }=\sqrt{\left[\frac{\left.\sum_{i=1}^{N}\left(\hat{P}_{i}-O_{i}\right)^{2}\right]}{N}\right]} \\
M S E u=\sqrt{\left[\frac{\sum_{i=1}^{N}\left(\hat{P}_{i}-P_{i}\right)^{2}}{N}\right]}
\end{gathered}
$$

Where,

$\widehat{P}_{i}=P$ value estimated by linear regression $\left(\hat{P}_{i}=a+b O_{i}\right)$.

\section{RESULTS AND DISCUSSION}

\section{Climatic conditions and crop coefficient $(K)$}

Total rainfall of $245.6 \mathrm{~mm}$ was recorded in winter, distributed over 44 days; the average $\mathrm{ET}_{\text {o }}$ for the period was $2.76\left( \pm 0.97 \mathrm{~mm}^{\mathrm{d}} \mathrm{d}^{-1}\right)$. Regarding spring, a greater total of rainfall of $767.6 \mathrm{~mm}$ was 
observed in 56 days and the average $\mathrm{ET}_{\mathrm{o}}$ for the period was $4.03\left( \pm 1.84 \mathrm{~mm}^{-\mathrm{d}^{-1}}\right)$. The total rainfall for the summer was $693.4 \mathrm{~mm}$, which occurred for 59 days. In the same period, an average $\mathrm{ET}_{\mathrm{o}}$ of 4.49 $\left( \pm 1.52 \mathrm{~mm} . \mathrm{d}^{-1}\right)$ was obtained. Autumn had a total rainfall of $582.2 \mathrm{~mm}$, distributed over 55 days, and an average ET of $2.78\left( \pm 0.85 \mathrm{~mm}^{-\mathrm{d}^{-1}}\right)$. The highest mean magnitude per event was observed in spring, followed by summer, while the lowest occurred in winter (Table 3 and Figure 1).

Also, according to the accumulated total for each season, it is observed that rainfall showed greater values than $\mathrm{ET}_{0}$ and $\mathrm{ETa}_{\beta}$ and this difference was more accentuated in the spring. As for the accumulated $\mathrm{ET}_{0}, \mathrm{ETa}_{\beta}$ and $\mathrm{ETa} \_\mathrm{ThM}$, they presented higher values in the summer, $408.5( \pm$ $\left.1.52 \mathrm{~mm} \cdot \mathrm{d}^{-1}\right), 377.9\left( \pm 1.39 \mathrm{~mm} \cdot \mathrm{d}^{-1}\right)$ and $411.5( \pm$ $\left.1.71 \mathrm{~mm} . \mathrm{d}^{-1}\right)$, respectively.

Regarding the $\mathrm{ET}_{\mathrm{o}}$ variation during the analyzed period, a trend of higher values was observed in the spring and summer, and a decrease in the values in the winter and autumn seasons. This fact indicated that $\mathrm{ET}_{\mathrm{o}}$ showed a relationship with the availability of solar radiation, as expected. A similar pattern was observed by Bueno et al. (2019), when evaluating the effect of irrigation on two grass species during the period from May/2018 to June/2019. The authors found that $\mathrm{ET}_{\mathrm{o}}$ was influenced by incident solar radiation and air temperature. Alencar et al. (2015) also found that solar radiation was the parameter that influenced $\mathrm{ET}_{\mathrm{o}}$ estimates the most.

Table 3. Precipitation $(\mathrm{P})$, reference $\left(\mathrm{ET}_{\mathrm{o}}\right)$ real $\left(\mathrm{ET}_{\mathrm{a}}\right)$ evapotranspiration from Thornthwaite e Mather model $\left(\mathrm{ET}_{\mathrm{a}-\mathrm{ThM}}\right)$ and Bowen ratio - energy balance $\left(\mathrm{ETa}_{\beta}\right)$ data description according to each season

\begin{tabular}{ccccccccc}
\hline \multirow{2}{*}{$\begin{array}{c}\text { Time } \\
\text { Couse }\end{array}$} & ETo & ETR_ThM & ETR $_{\beta}$ & $\mathrm{P}$ & P-ETo & P-ETR $_{\beta}$ & $\begin{array}{c}\mathrm{N}^{\circ} \text { rainy } \\
\text { days }\end{array}$ & Magnitude \\
\cline { 2 - 7 } & & & & $\mathrm{mm}$ & & & & \\
Winter & 231.9 & 199.9 & 210.6 & 245.6 & 13.7 & 35 & 44 & 5.6 \\
Spring & 362.4 & 342.5 & 323 & 767.6 & 405.2 & 444.6 & 56 & 13.7 \\
Summer & 408.5 & 377.9 & 411.5 & 693.36 & 284.9 & 281.8 & 59 & 11.8 \\
Autumn & 252.6 & 243 & 285 & 582.2 & 329.6 & 297.3 & 55 & 10.6 \\
Year & 1255.4 & 1163.3 & 1230.1 & 2288.76 & 1033.36 & 1058.66 & 214 & 10.7 \\
\hline
\end{tabular}

Magnitude $=$ total rainfall/number of rainy days; $\mathrm{P}=$ precipitation; ETa_ThM $=$ evapotranspiration estimated by the water balance of Thornthwaite and Mather (1955); $\mathrm{ETa}_{\beta}=$ evapotranspiration determined by the Bowen ratio.

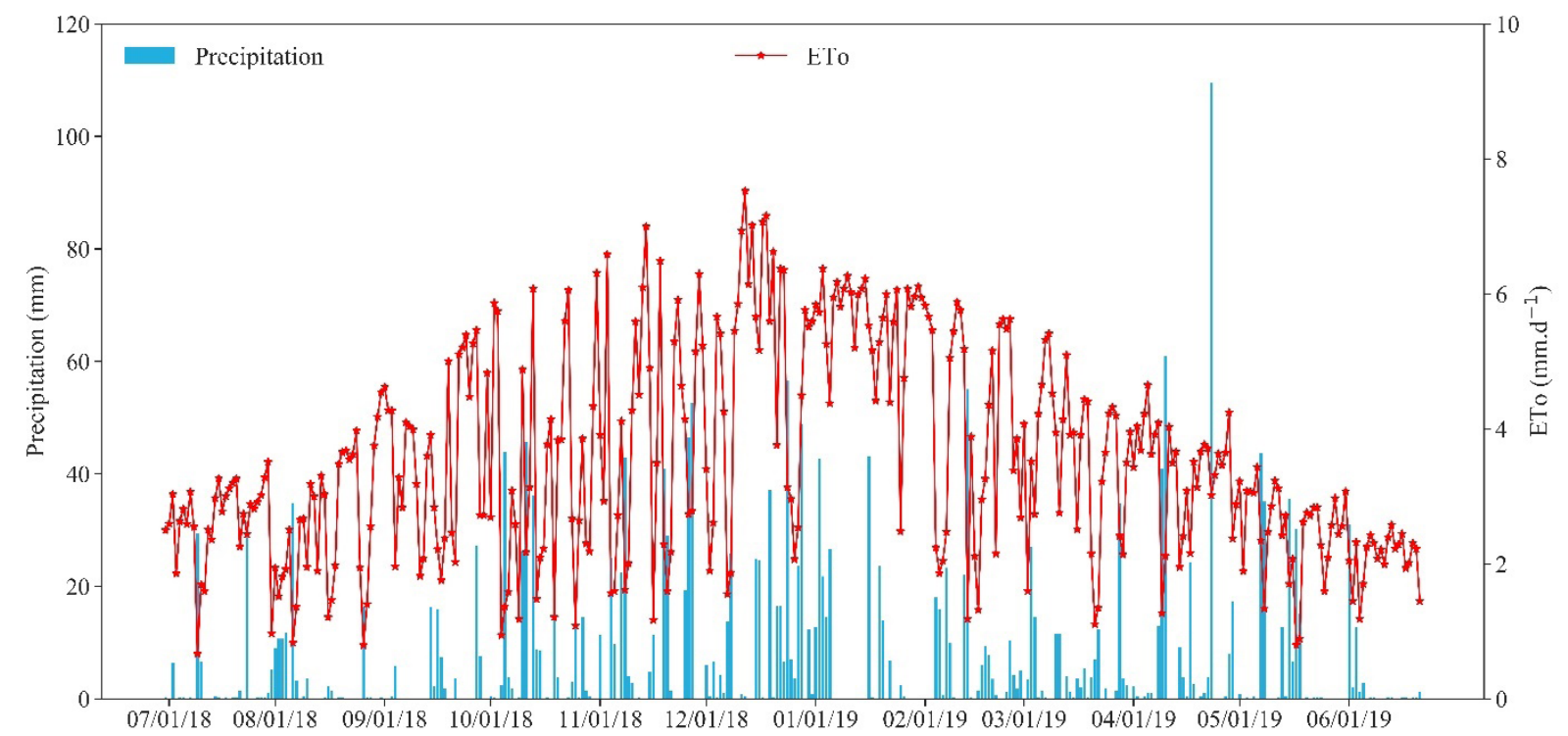

Figure 1. Rainfall variation and reference evapotranspiration $\left(\mathrm{ET}_{\mathrm{o}}\right.$ ) for the period from July 2018 to June 2019, corresponding to the winter; spring; summer, and autumn 
The fit of the linear regression used to determine the $\mathrm{K}_{c}$ showed high precision, being able to explain $97 \%$ of the data variability with EPE of 0.0052 (Figure 2). When assessing the relationship between $\mathrm{ET}_{\mathrm{c}}$ and $\mathrm{ET}_{\mathrm{o}}$, Graham et al., (2016) found that $\mathrm{ET}_{\mathrm{c}}$ explained $97 \%$ of $\mathrm{ET}_{\mathrm{o}}$. Santos et al. (2017) evaluated the regression between $\mathrm{ET}_{\mathrm{c}}$ and $\mathrm{ET}_{\mathrm{o}}$ for three of the phenological stages of Moringa, and observed an $\mathrm{R}^{2}$ of 0.99 for all stages.

According to the ANOVA, the ET, $\mathrm{ET}_{\mathrm{c}}$ data showed a significant relationship $(\mathrm{p}<0.01)$. The $\mathrm{K}_{\mathrm{c}}$ value of 1.04 corroborates the $\mathrm{K}_{\mathrm{c}}$ values for pastures shown in the literature (ANTONIEL et al., 2016; BARNOSA; OLIVEIRA; DE FIGUEIREDO, 2015; SANCHES et al., 2017a; SANTANA et al., 2016). Sanches et al. (2017b) when evaluating the average $\mathrm{K}_{\mathrm{c}}$ of Mombasa grass, also found values similar to those in this study (1.07). In addition, the authors observed that the $\mathrm{K}_{\mathrm{c}}$ values were not influenced by seasonality.

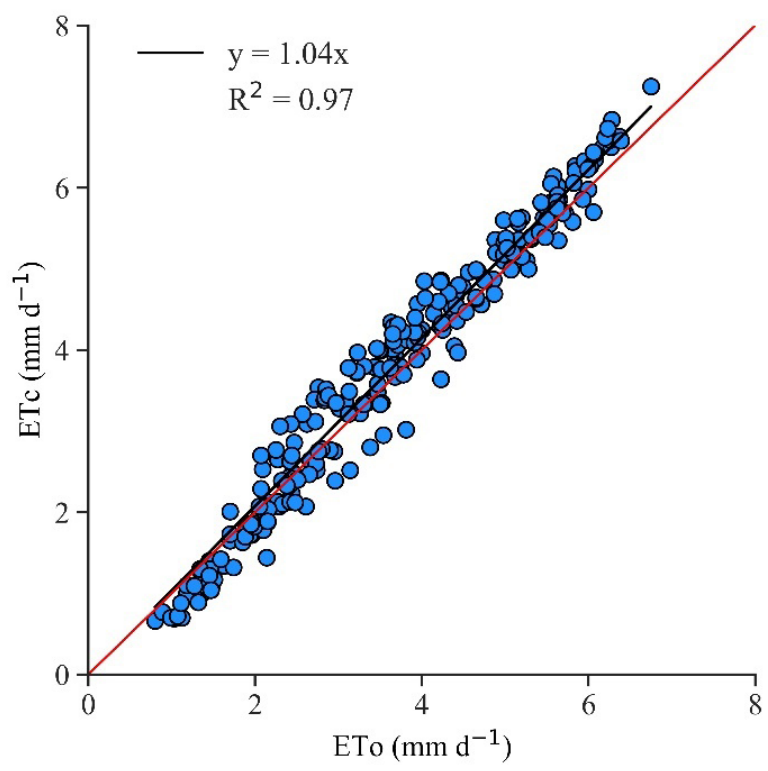

Figure 2. Linear regression between the observed values of reference evapotranspiration (ET) by the Penman-Monteith FAO56 method, and the values determined by $\mathrm{ET}_{\mathrm{c}}$ by the Bowen ratio - energy balance method for the fraction of available water between 0.8 and 1.1

Performance of the Thornthwaite and Mather model

In general, $\mathrm{ET}_{\mathrm{a}}$ estimates were less dispersed in autumn and spring, which presented $\mathrm{R}^{2}$ of 0.84 and 0.83 , respectively. The season with the largest dispersion was winter, followed by summer, with $\mathrm{R}^{2}$ of 0.43 and 0.56 , respectively. Except for the spring, it was observed that the ET $\mathrm{a}_{\mathrm{a}}$ estimated by the ThM model was underestimated concerning the $\mathrm{ET}_{\mathrm{a}}$ determined by the BREB (Figures 3 and 4). For winter and summer, an average underestimation of $11 \%$ was observed, while in the autumn period, the underestimation was $16 \%$. Silva et al. (2016) found an $\mathrm{R}^{2}$ of 0.83 in the winter period when evaluating the ET estimate calculated using Penman-Monteith and Bowen's ratio in an area cultivated with Bahia grass. Gomes et al. (2015b), when evaluating ET estimates of brachiaria decumbens performed using a simulation model of energy flux transfer, in relation to ET determined by Bowen's method, found a higher $\mathrm{R}^{2}$ value, of 0.91 .
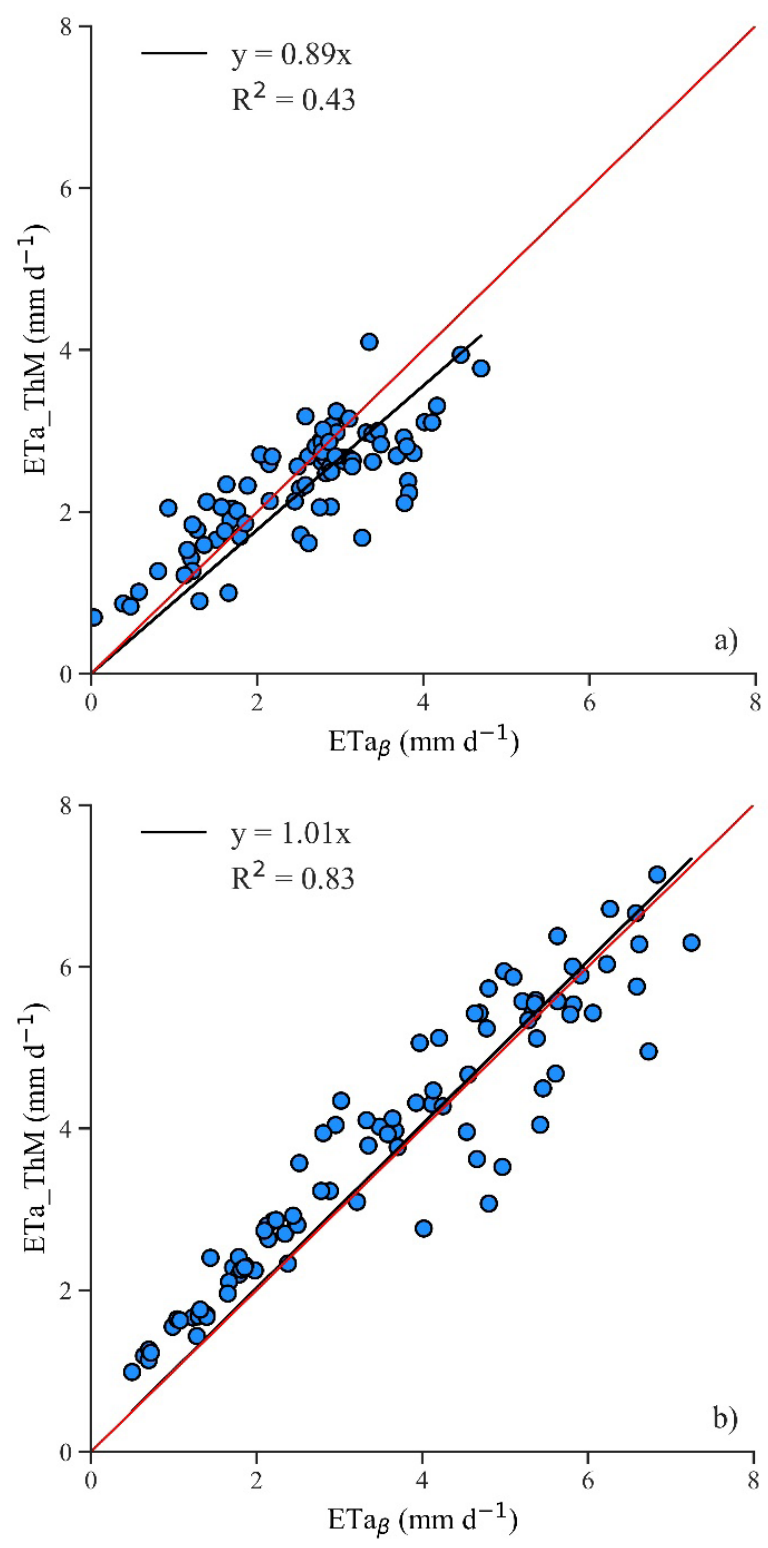

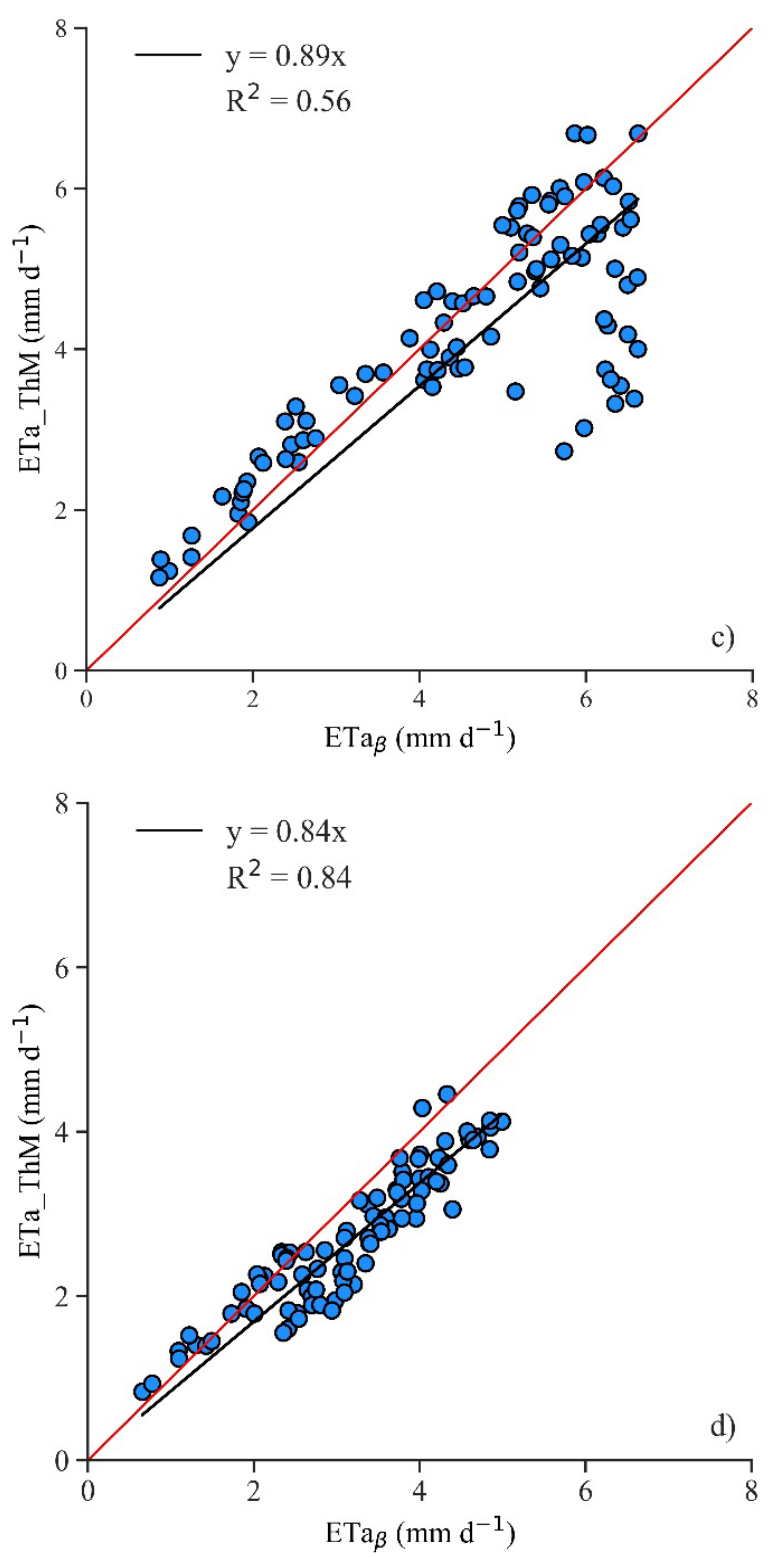

Figure 3. Linear regression between the actual daily evapotranspiration values (ETa, mm $\mathrm{d}^{-1}$ ) observed by the Bowen ratio method in relation to the ETa estimated by the soil water balance model for winter (a); spring (b); summer (c) and autumn (d)

In relation to the accuracy of the $\mathrm{ET}_{\mathrm{a}} \mathrm{ThM}$ estimates, the highest $\mathrm{d}_{\mathrm{m}}$ value was observed in the spring (0.82), followed by summer (0.73). Autumn and winter showed less accuracy, with values of 0.68 and 0.66 , respectively (Table 4). As for the error, the months corresponding to spring presented lower RMSE\% and the lowest error related to the model and its parameters, that is, systematic error,
MSEs\%. In contrast, the period with the highest RMSE\% was winter.

The highest values of systematic error were observed in autumn and winter. It is worth mentioning that both periods are characterized by a lower incidence of solar radiation and air temperature, which provides a slower pasture growth in relation to spring and summer, and reflects in a smaller leaf area of the canopy and height of the crop (ZHUANG et al., 2020). Thus, the higher MSEs\% values are probably the result of the use of a constant $\mathrm{K}_{\mathrm{c}}$, considering that it is intrinsically related to the ratio between the total area of the canopy and the occupied area of the soil, defined as the leaf area index (LAI) and the height of the crop. Bueno et al. (2019) found that after eight cuts of two pasture species, the largest dry and fresh matter yield occurred in the period from November to January, corresponding to summer, which indicates that seasonality influences the forage.

Although summer had a higher total rainfall than autumn, the greater dispersion of the $\mathrm{ET}_{\mathrm{a}}$ estimates observed in the summer can be explained by the lower frequency between the occurrence of the rainfall. This fact may have corroborated the greater ETR penalty estimated by the BH method, due to the low storage of water in the soil, which also explains the greater dispersion obtained in winter, which was the period of lowest total rainfall observed.

The method proposed by Thornthwaite and Mather when adapted to the crops penalizes the $\mathrm{ET}_{\mathrm{a}}$ more rigorously than other models, such as, for example, the dual Kc Furtado (2017), considering that the removal of water from the soil is caused by the exponential and the initial penalty immediately when soil water storage is less than the available water capacity, while the replacement is carried out directly, through the sum between the storage value and the positive balance between precipitation and ET (PEREIRA; SEDIYAMA; NOVA, 2013).

Another possible factor responsible for the underestimation of the values from the $\mathrm{ET}_{\mathrm{a}}$ estimated by SWB is due to the type of soil of the 


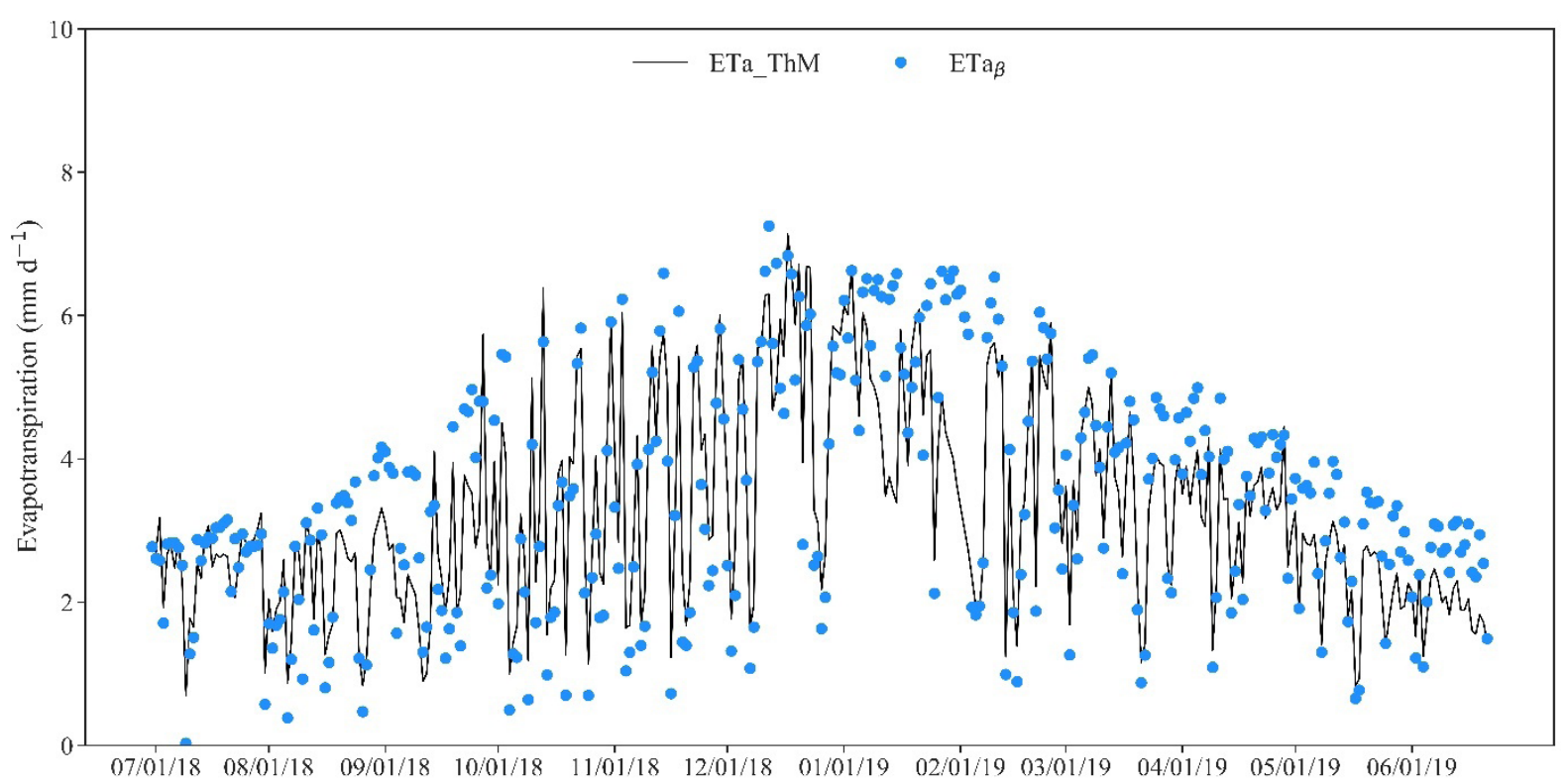

Figure 4. Variation in actual evapotranspiration $\left(\mathrm{ET}_{\mathrm{a}}\right)$, determined by Bowen $(\mathrm{ETa} \beta)$ and estimated by BH (ET $\_$ThM), analyzed during the period from July 2018 to June 2019, corresponding to the winter; spring; summer, and autumn

Table 4. Results of the statistical indicators used to assess the performance of the ThM water balance model, in the ETa estimate. Modified Willmott agreement index $\left(\mathrm{d}_{\mathrm{m}}\right)$, root mean square error (RMSE, \%), systematic mean square error $\left(\mathrm{MSE}_{\mathrm{s}}, \%\right)$ and unsystematic mean square error $\left(\mathrm{MSE}_{\mathrm{u}}, \%\right)$

\begin{tabular}{ccccc}
\hline Seasons & $\mathrm{d}_{\mathrm{m}}$ & RMSE $\%$ & MSEs $\%$ & MSEu $\%$ \\
Winter & 0,66 & 24,41 & 54,81 & 45,19 \\
Spring & 0,82 & 18,6 & 32,44 & 67,56 \\
Summer & 0,73 & 23,76 & 41,56 & 58,44 \\
Autumn & 0,68 & 19,66 & 71,53 & 28,47 \\
\hline
\end{tabular}

study site, considering that it has a high level of groundwater. This characteristic can contribute to the occurrence of capillary rise, a phenomenon not quantified by the SWB proposed by Thornthwaite and Mather.

\section{CONCLUSIONS}

- The Thornthwaite and Mather soil water balance model adapted for pasture presents satisfactory estimates of the real evapotranspiration, particularly in periods with higher rainfall frequency;

- Indry periods and or with less rainfall frequency, the model presents less performance, due to the intrinsic penalty to soil water balance;
- The use of a single crop coefficient constant throughout the year does not represent seasonal variations in leaf area index and crop height; and

- The model is more accurate, especially in the spring and autumn.

\section{AUTHORSHIP CONTRIBUTION STATEMENT}

BARROS, F.C.: Data curation, Methodology, Validation, Visualization, Writing - original draft; MARTINS, S.C.F.M.: Data curation, Investigation, Methodology, Writing - review \& editing; LYRA, G.B.: Conceptualization, Funding acquisition, Project administration, Supervision, Writing - review \& editing; SILVA, L.D.B.: Conceptualization, Methodology, Project 
administration, Resources, Writing - review \& editing; FRANCISCO, J.P.: Data curation, Formal Analysis, Software, Validation, Writing - review \& editing; ABREU, M.C.: Formal Analysis, Funding acquisition, Investigation, Software, Visualization; LYRA, G.B.: Data curation, Project administration, Resources, Writing - review \& editing.

\section{DECLARATION OF INTERESTS}

The authors declare that they have no knowledge of a conflict of interest that could have appeared to influence the work reported in this paper.

\section{REFERENCES}

AGUIAR, D. A.; MELLO, M. P.; NOGUEIRA, S. F.; GONÇALVES, F. G.; ADAMI, M.; RUDORFF, B. F. T. MODIS time series to detect anthropogenic interventions and degradation processes in tropical pasture. Remote Sensing, v. 9, n. 1, p. 1-20, 2017.

ALENCAR, L. P.; SEDIYAMA， G. C.; MANTOVANI, E. C. Estimativa da evapotranspiração de referência (ETo padrão FAO), para Minas Gerais, na ausência de alguns dados climáticos. Engenharia Agrícola, v. 35, n. 1, p. 39-50, 2015.

ALVARES, C. A.; STAPE, J. L.; SENTELHAS, P. C.; DE MORAES GONÇALVES, J. L.; SPAROVEK, G. Köppen's climate classification map for Brazil. Meteorologische Zeitschrift, [s. 1.], v. 22, n. 6, p. 711-728, 2013.

ANTONIEL, L. S.; PRADO, G.; TINOS, A. C.; BELTRAME, G. A.; ALMEIDA, J. V. C. De; CUCO, G. P. Pasture production under different irrigation depths. Revista Brasileira de Engenharia Agrícola e Ambiental, [s. 1.], v. 20, n. 6, p. 539-544, 2016.

BARBOSA, B. D. S.; OLIVEIRA, F. G.; DE FIGUEIREDO, F. P. Determinação do coeficiente de cultivo $(\mathrm{Kc})$ do capim tanzânia irrigado no norte de minas gerais. Irriga, v. 1, n. 2, p. 11-20, 2015.
BOSI, C.; SENTELHAS, P. C.; HUTH, N. I.; PEZZOPANE, J. R. M.; ANDREUCCI, M. P.; SANTOS, P. M. APSIM-Tropical Pasture: A model for simulating perennial tropical grass growth and its parameterisation for palisade grass (Brachiaria brizantha). Agricultural Systems, v. 184, n. March, p. 102917, 2020.

BOWEN, I. S. The ratio of heat losses by conduction and by evaporation form any water surface. Hydrology and Earth System Sciences, v. 27, n. 2 , p. $779-787,1926$.

BUENO, J. I.; DO PRADO, G.; TINOS, A. C.; BRUSCAGIN, R. R.; VOLPATO, G. R. Produção sazonal de duas espécies forrageiras irrigadas. Irriga, v. 24, n. 2, p. 289-302, 2019.

CRUZ, G. H. T.; SANTOS, L. da C.; SILVA, S. M. da C.; REIS, E. F. Dos. Desempenho de métodos de estimativa da evapotranspiração de referência para o município de Rio Verde-GO. Revista Brasileira de Agricultura Irrigada, v. 11, n. 6, p. 1854-1861, 2017.

FAO. The future of food and agriculture Alternative pathways to 2050. Summary Ve ed. Rome.

FURTADO, T. F. Comparação de modelos para estimativa do conteúdo de água no solo em cultivo de milho do município de Arapiraca, AL. 2017. 64f. Dissertação de Mestrado, Universidade Federal Fluminense, Rio de Janeiro, 2017.

GOMES, C. de A.; LIMA, J. R. de S.; ANTONINO, A. C. D.; SOARES, W. de A.; SOUZA, E. S. De; RIBEIRO, A. A.; ALVES, E. M.; MACHADO, C. B.; FIRMINO, F. H. T. Medição e simulação dos fluxos de energia e evapotranspiração em solo cultivado com brachiaria decumbens na microrregião de Garanhuns-PE. Revista Brasileira de Geografia Física, v. 06, p. 365-376, 2015. a.

GOMES, E. P.; RICKLI, M. E.; CECATO, U.; VIEIRA, C. V; SAPIA, J. G.; SANCHES, A. C. Produtividade de capim tifton 85 sob irrigação e doses de nitrogênio. Revista Brasileira de Engenharia Agrícola e Ambiental, p. 317-323, 2015. b. 
GRAHAM， S. L.; KOCHENDORFER， J.; MCMILLAN, A. M. S.; DUNCAN, M. J.; SRINIVASAN, M. S.; HERTZOG, G. Effects of agricultural management on measurements, prediction, and partitioning of evapotranspiration in irrigated grasslands. Agricultural Water Management, v. 177, p. 340-347, 2016.

LYRA, G. B.; LYRA, G. B.; SOUZA, J. L. De; SANTOS, M. A. Balanço Seqüencial de Água no Solo para o Manejo da Irrigação de Baixa Freqüência e Alta Intensidade na Cana-de-Açúcar. STAB v. 28, n. May 2014, p. 22-25, 2010.

LYRA, G. B.; PEREIRA, A. R. Dificuldades de estimativa dos parâmetros de rugosidade aerodinâmica pelo perfil logarítmico do vento sobre vegetação esparsa em região semi-árida. Revista Brasileira de Geofísica, v.25, n.2, p. 87-197, 2007.

MONTEITH, J. L.; UNSWORTH, M. H. Principles of environmental physics, 2nd Edition. Edward Arnold, London, 1990.

O'REILLY, A. M.; HOLT, R. M.; DAVIDSON, G. R.; PATTON, A. C.; RIGBY, J. R. A Dynamic Water Balance/Nonlinear Reservoir Model of a Perched Phreatic Aquifer-River System With Hydrogeologic Threshold Effects. Water Resources Research, v. 56, n. 6, p. 0-3, 2020.

PEREIRA, A. R.; SEDIYAMA, G. C.; NOVA, N. A. V. Evapotranspiração. 1 ed. Campinas, SP, Fundag, 2013.

PEREZ, P. J.; CASTELLVI, F.; IBAÑEZ, M.; ROSELL, J. I. . Assessment of reliability of Bowen ratio method for partitioning fluxes. Agricultural and Forest Meteorology, v. 97, n. 3, p. 141-150, 1999.

RETORE, M.; JUNIOR, F. M. V.; BRITEZ, G. D. V.; ROSSATTI, J. A.; RICHETTI, A. Do pasto ao prato: a alimentação do cordeiro influencia na qualidade da carne? Embrapa, n.1679-472, p.1-7, 2019.

SANCHES, A.C.; SOUZA, D.P; JESUS, F.L.F.; MENDONÇA, F.C.; MAFFEI, R.G. Consumo de água de forrageiras tropicais no período de formação de pastagem. Revista Brasileira de Agricultura Irrigada, v. 11, n. 2, p. 1291-1301, 2017a.
SANCHES, A. C.; SOUZA, D. P.; JESUS, F. L. F.; MENDONÇA, F. C.; GOMES, E. P. Water consumption estimate for mombaça and cynodon spp. grasses in exclusive cropping and overseeded with winter forage. January, $2017 \mathrm{~b}$.

SANTANA, M. J. De; WACHSMUTH, R.; SGOBI, M. A.; ALMEIDA, F. da S. Evapotranspiração e coeficiente de cultura do tifton-85 em Uberaba, MG. Global Science and Technology, v. 9, n. 1984-3801, p. 39-50, 2016.

SANTOS, C. S. Dos; MONTENEGRO, A. A. d. A.; DOS SANTOS, M. A. L.; PEDROSA, E. M. R. Evapotranspiration and crop coefficients of Moringa oleifera under semi-arid conditions in Pernambuco. Revista Brasileira de Engenharia Agricola e Ambiental, [s. 1.], v. 21, n. 12, p. 840845, 2017.

SILVA, L. D. B. Da; LYRA, G. B.; SILVA, J. B. G.; PINHO, C. F. De; NASCENTES, A. L.;ALMEIDA, G. V. De; FOLEGATTI, M. V. Desempenho do método do balanço de energia - razão de Bowen na estimativa da evapotranspiração de referência. Irriga, v. 21, n. 3, p. 516, 2018.

WALLS, S.; BINNS, A. D.; LEVISON, J.; MACRITCHIE, S. Prediction of actual evapotranspiration by artificial neural network models using data from a Bowen ratio energy balance station. Neural Computing and Applications, v. 32, n. 17, p. 14001-14018, 2020.

WILLMOTT, C. J.; ROBESON, S. M.; MATSUURA, K. A refined index of model performance. International Journal of Climatology, v. 32, n. 13, p. 2088-2094, 2012.

ZHUANG, W.; SHI, H.; MA, X.; CLEVERLY, J.; BERINGER, J.; ZHANG, Y.; HE, J.; EAMUS, D.; YU, Q. Improving Estimation of Seasonal Evapotranspiration in Australian Tropical Savannas using a Flexible Drought Index. Agricultural and Forest Meteorology, v. 295, n. February, p. 108203, 2020. 